кандидат педагогічних наук, доцент

(Житомирський державний університет імені Івана Франка)

\title{
СПЕЦИФІКА ПІДГОТОВКИ МАЙБУТНІХ ФАХІВЦІВ СОЩІАЛЬНОЇ СФЕРИ У ВІТЧИЗНЯНІЙ ВИЩІЙ ШКОЛІ ЯК ЧИННИК БІЛІНГВАЛЬНОЇ ПРОФЕСІЙНОЇ ПІДГОТОВКИ
}

У даній статті представлено специифіку підготовки майбутніх фахівців соціальної сфери у вітчизняній вищій школі, яка виступає чинником професійної підготовки таких фахівців на білінгвальній основі. Доведено, щчо з точки зору освітніх потреб та можливих способів їх реалізачії, на сучасному етапі розвитку українського суспільства білінгвальна освіта є необхідним елементом підготовки сучасного фахівия сочіальної сфери.

Ключові слова: білінгвальна професійна підготовка, навчання на білінгвальній основі, фахівці сочіальної сфери.

Актуальність постановки проблеми дослідження. Держава, як форма організації правління, має ряд соціальних інститутів, покликаних на забезпечення ії соціальної політики. Одним із інструментів реалізації соціальної політики будь-якої держави $є$ професійна соціальна робота. Соціальна робота - це вид діяльності державних і недержавних інституцій, організацій, груп та окремих індивідів, спрямованих на соціальну підтримку людей у суспільстві [1].

Ключовими суб'єктами такої діяльності держави виступають соціальні працівники, які покликані професійно допомагати усім соціально незахищеним прошаркам населення вирішувати проблеми, що виникають у їх повсякденному житті. Вони не тільки знімають соціальну напруженість, але і беруть участь у розробці законодавчих актів, покликаних більш повно виразити інтереси різних верств населення, тим самим вдосконалюючи систему соціальної роботи. Це спричиняє об'єктивну необхідність належної підготовки фахівців соціальної сфери. Соціальна робота у кризовій соціально-економічній ситуації, у якій перебуває Україна, є ще більш актуальною та необхідною, оскільки все більша частина населення стає клієнтами ії соціальних служб. А українське суспільство в умовах загостреної соціально-економічної кризи відчуває нагальну потребу у кваліфікованих фахівцях для ії умілого та ефективного здійснення. Варто також відзначити, що кризова ситуація, яка спостерігається на сьогоднішній день в Україні, спричинила певні негативні тенденції у багатьох напрямках соціальної сфери: зменшення чисельності населення, збільшення кількості розлучень, а отже і проблемних сімей, сиріт, відбувається старіння населення, зубожіння, а тому поширюється жебрацтво, через неякісне медичне обслуговування зростає кількість неповноцінних дітей, інвалідів, широко розповсюджені захворювання на венеричні хвороби, у тому числі на СНІД, що зазвичай трапляється під час суспільних негараздів, зростає захворюваність на наркоманію і токсикоманію, зростає злочинність. На ускладнення ситуації у соціальній сфері вплинули і геополітичні процеси, що відбуваються у суспільстві, які супроводжуються збільшенням кількості мігрантів у нашій країні [2].

Інтенсивний розвиток соціальної сфери, розширення кадрового ресурсу, що спостерігається в останнє десятиліття в Україні, поглиблення існуючих та поява нових проблем соціально-економічного та соціокультурного характеру, загострення потреб вразливих категорій населення, на яких і спрямовується діяльність фахівців соціальної сфери, потребують підвищення уваги до надання відповідних професійних знань, специфічних умінь та навичок фахівців, які виступають у ролі суб'єкта-об'єкта соціальної перцепції. Надання якісних послуг різним категоріям клієнтів потребує від фахівця як долучення до світових сучасних здобутків у цій сфері для запозичення позитивного досвіду вирішення тих чи інших проблем, так і участі фахівців у міжнародних проектах для забезпечення міжнародної співпраці у цій галузі, обміну досвідом, постійного розвитку фахівця та його самовдосконалення. Зважаючи на полілінгвальність клієнтів, потребу міжнародної співпраці, можливості запозичення позитивного зарубіжного досвіду та розширення можливостей саморозвитку і самовдосконалення, набуває актуальності професійна підготовка майбутніх фахівців соціальної сфери на білінгвальній основі, тобто розвиток професійної комунікативної компетентності як рідною, так і іноземною мовами. Адже сучасний ринок соціальних послуг диктує потребу у білінгвальних фахівцях соціального профілю.

Таким чином, метою статті є: окреслення специфіки підготовки майбутніх фахівців соціальної сфери у вітчизняних закладах вищої освіти - як чинника білінгвальної професійної підготовки таких фахівців.

Оскільки процес підготовки будь-яких фахівців є складним і тривалим, він потребує особливої уваги і належної організації системи професійної підготовки.

Загалом процес формування системи професійної підготовки майбутніх фахівців соціальної сфери в умовах закладу вищої освіти регламентується низкою нормативних документів, у яких відображено мету, 
завдання освітньо-професійної підготовки, предмет діяльності майбутнього фахівця соціальної сфери, визначено головні функції такого роду фахівців та вимоги, які висуваються до фахівців соціальної сфери, а також місце таких фахівців в державній системі соціального захисту. Всі ці положення відображаються в освітній програмі зі спеціальності, яка підпорядковується головному документу щодо освітньокваліфікаційної характеристики фахівця - Державному галузевому стандарту [3].

На основі зазначених регламентуючих документів та відповідно до соціальних викликів, у практиці діяльності вітчизняної вищої школи сформувалися різноманітні підходи щодо підготовки майбутніх фахівців соціальної сфери: системний, особистісно-діяльнісний, індивідуально-творчий і інші [4]. Зазначені підходи знайшли своє відображення у сучасних наукових дослідженнях (І. Звєрєва, Р. Вайнола, С. Сисоєва, А. Капська, Л. Міщик, В. Поліщук, С. Харченко), в яких були розроблені теоретичні засади підготовки майбутніх фахівців соціальної сфери в умовах неперервної освіти, визначено основні змістові, процесуальні особливості підготовки їх до соціальної та соціально-педагогічної діяльності.

У межах нашого дослідження хотілося б виділити доробки професорів Р. Вайноли, А. Капської, В. Поліщук, С. Сисоєвої та інших.

Так, професор В. Поліщук професійну підготовку фахівців соціальної сфери розглядає як процес і як результат оволодіння професійно-необхідними знаннями, уміннями, навичками, а також цінностями соціально-педагогічної діяльності, професійно-важливими особистісними якостями, які $\epsilon$ базисом формування готовності до професійної соціальної діяльності. Також професорка акцентує на специфічних знаннях, уміннях та навичках, що притаманні даній професії, наголошуючи, що розвиток особистісних якостей у цьому випадку є професійною необхідністю [5: 139-142].

Науковці Р. Вайнола, С. Сисоєва наголошують на важливості особистісного розвитку фахівця соціальної сфери у процесі професійної підготовки. На основі теоретичного узагальнення ними запропоновано особливий підхід до розв'язання проблеми особистісного розвитку майбутнього фахівця соціальної сфери в процесі професійної підготовки в умовах закладу вищої освіти, що знайшло своє відображення в розробці й обгрунтуванні педагогічних засад особистісного розвитку майбутнього фахівця соціальної сфери у закладі вищої освіти [4].

Професорка А. Капська вважає, що процес професійної підготовки фахівців соціальної сфери не повинен виступати пасивним віддзеркаленням соціального розвитку держави, а навпаки має бути спрямований на активний пошук розв'язання нагальних соціальних проблем. На ії думку, зміст підготовки фахівців соціальної сфери повинен включати наступні компоненти: аналіз стану соціального розвитку та розвиток умінь своєчасної оцінки тенденцій соціальної політики у державі; чітке уявлення щодо змісту та класифікації сучасних форм, методів, практики соціальної роботи; педагогічний процес підготовки фахівців соціальної сфери, розробка теорій, концепцій, моделей та технологій, спрямованих на ефективне функціонування освітнього процесу; розробка та реалізація програм, спрямованих на підвищення професійної компетентності фахівців соціальної сфери [6: 19-29].

Підтримуючи підходи вищезгаданих науковців щодо змісту підготовки фахівців соціальної сфери та зважаючи на специфічність професії і різноманітність клієнтів (з якими будуть у майбутньому працювати фахівці соціальної сфери), сучасні зміни в соціально-економічній та соціокультурній сферах життєдіяльності суспільства, глобалізаційні тенденції загалом, нові кваліфікаційні вимоги до професійної підготовки майбутніх фахівців соціальної сфери, вважаємо доцільним розширити перелік означених компонентів щодо змісту та форм їх підготовки можливістю надання фахівцям соціальної сфери професійної підготовки на білінгвальній основі.

Варто зазначити, що пошуком ефективних шляхів професійної підготовки фахівців соціальної сфери займалися також В. Бочарова, Ю. Галагузова, І. Звєрєва, Н. Сейко. Свої наукові дослідження щодо пошуку нових технологій, форм і методів ефективної професійної підготовки фахівців соціальної сфери присвятили I. Мигович, Н. Платонова, Є. Холостова. Ці дослідження були викликані рядом соціально-економічних та соціокультурних чинників, які спричинили численні соціальні проблеми в державі в кінці XX - на початку XXI століття: війна на Сході, зростання цін, низький рівень зарплат та пенсій, безробіття, високі комунальні тарифи та інші. Вони викликали потребу в соціальному захисті та підтримці незахищених прошарків населення (біженці, мігранти, внутрішньо-переміщені особи, інваліди), набуття молодими фахівцями соціального та професійного досвіду, що і викликало потребу великої кількості висококваліфікованих фахівців соціальної сфери. Система професійної університетської підготовки була покликана забезпечити українське оновлене суспільство такими фахівцями.

Окрім того, специфічною особливістю сучасного українського суспільства стала його багатомовність, що почало вимагати від сучасного фахівця соціальної сфери полілінгвальних комунікативних знань та умінь для забезпечення як особистого професійного розвитку та самовдосконалення, так і розширення можливостей надавання професійної допомоги клієнтам.

Нині підготовкою фахівців соціальної сфери в Україні займаються навчальні заклади вищої освіти, фахової передвищої освіти та професійної освіти. Кількість навчальних закладів, які готують фахівців соціальної сфери різних спеціальностей і рівнів кваліфікації постійно збільшується [7: 82-86]. 
Введення інституції професійної підготовки фахівців соціальної сфери було обумовлене потребою у фахівцях, здатних оволодіти сучасними технологіями соціальної та соціально-педагогічної роботи, сукупністю професійних дій, спрямованих на встановлення, збереження чи поліпшення соціального функціонування дітей та молоді, а також на попередження негативних соціальних процесів. Тому головною метою діяльності фахівців соціальної сфери є створення умов для саморозвитку, самоствердження особистості, підтримки і стимулюванні людини до активної життєдіяльності [4].

Сучасний фахівець соціальної роботи - це професіонал, який добре орієнтується в питаннях соціальних відносин, у правових гарантіях громадян, чітко визначає морально-психологічні проблеми життєдіяльності людей і здатний кваліфіковано надати їм відповідну ситуації допомогу. Окрім теоретичних знань, соціальна робота вимагає і глибокої технологічної підготовки, що виражається в наявності навичок у сфері соціальнопсихологічного і ситуаційного аналізу, соціально-організованої діагностики умов життєдіяльності різних груп населення, проведення конкретно-соціологічних досліджень, прогнозування і виявлення тенденцій розвитку соціальних процесів, оптимального вибору інструментарію, що регулює їх перебіг [8].

Професії "соціальний працівник", "фахівець із соціальної роботи", "соціальний педагог" були офіційно зареєстровані в українських державних документах у 1993 році і створені для вирішення соціальних проблем людини і суспільства. 32016 року, згідно оновленого "Національного класифікатора професій 2016", перелік професій фахівців соціальної сфери було зведено до наступних: "соціальний аудитор", "соціальний патолог", "соціальний працівник", "соціальний працівник (допоміжний персонал)", "соціальний робітник" [9]. Тому в подальшому для спрощення викладення результатів дослідження $€$ доречним об'єднати їх єдиним поняттям "фахівець соціальної сфери". Підготовку фахівців такої групи професій, з точки зору вищої освіти, здійснюють ЗВО України у межах галузі знань "Соціальна робота".

Фахівці соціальної сфери з рівнем вищої освіти $є$ домінуючими серед усього переліку професій $\mathrm{i}$ фахівців цієї сфери. Саме вони організовують та здійснюють найбільш вагомі види професійної діяльності: організаційно-методичну роботу з різними категоріями населення, соціальну підтримку вразливих груп населення, соціальну просвіту, соціальну профілактику негативних явищ та ін. Їх підготовка на відповідному рівні надасть можливість належно виконувати свої функціональні обов'язки та завдання державних і недержавних структур соціальної сфери діяльності. Однак, у межах нашого дослідження, вважаємо доцільним детально зупинитися на основній спеціальності, за якою здійснюють підготовку фахівців відповідної галузі знань переважна більшість ЗВО України - "соціальний працівник".

Дати чітке визначення професії "соціальний працівник" складно через різноманітні підходи до самої соціальної роботи, широкий спектр клієнтів, які працюють із соціальними працівниками та різноманітні послуги, які надають соціальні працівники у процесі своєї професійної діяльності. Вважаємо доцільним розглянути цю спеціальність через призму самої соціальної роботи, з якої і випливає мета, головні завдання, принципи та напрямки роботи соціальних працівників [10].

Соціальну роботу різні науковці розглядають по-різному. Так, Т. Семигіна вважає, що соціальна робота - це наука і мистецтво розширення сфери соціальних взаємодій людей, їх активної адаптації до нових реалій життя, повноцінної ролі в суспільстві; професійна або волонтерська діяльність, спрямована на гарантовану підтримку і надання соціальних послуг будь-якій людині [11].

І. Звєрєва, Л. Коваль розглядали соціальну роботу як сферу людської діяльності, функції якої полягають у виробленні теоретичної систематизації об'єктивних знань про певну дійсність - соціальну сферу та специфічну соціальну діяльність. О. Безпалько трактувала соціальну роботу як різновид людської діяльності, метою якої є оптимізувати здійснення суб'єктивної ролі людей у всіх сферах життя суспільства у процесі забезпечення життєдіяльності існування особистості, сім'ї, соціальних та інших груп і верств суспільства [10].

Найближчим до нашого дослідження, у процесі якого має бути виділена специфіка підготовки фахівців соціальної сфери закладами вищої освіти, вважаємо визначення Т. Семигіної та І. Миговича, які вважають, що соціальний працівник (фахівець соціальної сфери) покликаний допомогти розширенню сфери соціальних взаємодій людей, їх активної адаптації до нових реалій життя, повноцінної ролі в суспільстві; їх діяльність спрямована на гарантовану підтримку і надання соціальних послуг будь-якій людині [10].

Об'єктами соціальної роботи є люди, які потребують сторонньої допомоги. Усі функції щодо надання допомоги тим, хто їі потребує виконують суб'єкти соціальної роботи.

Фахівець 3 соціальної роботи наділений різноманітними посадовими обов'язками. Основні 3 них такі, що він повинен: володіти основами пенсійної справи, соціального захисту сімей з дітьми, інвалідів, одиноких та інших соціальне незахищених громадян; виявляти на підприємствах, в мікрорайонах, селах сім'ї окремих осіб, які потребують соціально-медичну, юридичну, психолого-педагогічну, матеріальну й іншу допомогу, охорону морального, фізичного і психічного здоров'я; встановлювати причини виникаючих у них труднощів, конфліктних ситуацій, в т.ч. за місцем роботи, навчання і т.д., допомагати їм у розв'язанні існуючих проблем, працевлаштуванні, соціальному захисті; сприяти інтеграції діяльності різних державних і громадських організацій та установ по наданню необхідної соціально-економічної допомоги населенню; проводити психолого-педагогічні та юридичні консультації з питань сім'ї і шлюбу, виховну роботу серед 
дітей, схильних до правопорушень; надавати допомогу в укладанні угод про надомну працю батькам, що мають неповнолітніх дітей, інвалідам, пенсіонерам, внутрішньо-переміщеним особам, учасникам АTO і іншим категоріям; виявляти і надавати підтримку дітям та дорослим, яким потрібна опіка і піклування, влаштування в лікувальні й учбово-виховні заклади, матеріальна, соціально-побутова та інша допомога; організовувати громадський захист неповнолітніх правопорушників при необхідності - брати в ньому особисту участь; сприяти створенню і діяльності центрів соціальної служби для молоді, допомоги сім'ї (всиновлення, опікунство, піклування), юнацьких, підліткових, дитячих об'єднань, асоціацій, клубів за інтересами; брати участь в роботі по соціальній адаптації і реабілітації осіб, які повернулися з спеціальних навчально-виховних установ і місць позбавлення волі, розв'язанні інших гострих соціальних проблем.

Різноманітні професійні вимоги до фахівця із соціальної роботи витікають 3 таких його головних функцій: діагностична, прогностична, правозахисна, організаційна, профілактична, соціально-медична, соціально-педагогічна, технологічна, соціально-побутова і комунікативна, які в свою чергу, визначають особливості підготовки майбутніх фахівців цієї сфери [11].

Діагностична функція соціального працівника полягає у вивченні особливостей сім'ї, групи людей, ступеню й спрямованості впливу на них мікросередовища і постановці відповідного "соціального діагнозу". 3 його врахуванням прогнозується розвиток подій, процесів, моделі соціальної поведінки. В разі потреби використовуються закони і правові акти з метою надання допомоги і підтримки людей, їхнього захисту.

Велику увагу соціальний працівник повинен приділяти попередженню і профілактиці негативних явищ, приводячи в дію різні механізми (юридичні, психологічні, медичні, педагогічні та ін.), організовуючи відповідну допомогу особам, що ії вкрай потребують. Безпосередня соціально-медична функція працівника соціальних служб полягає в організації роботи з профілактики здоров'я, засвоєнні навичок першої медичної допомоги, підготовці молоді до сімейного життя, в розвитку трудотерапії та ін.

Багатопланова його соціально-педагогічна функція: виявляти інтереси й потреби людей у різних видах діяльності (культурно-освітній, спортивно-оздоровчій, науково-технічній) і залучати до роботи 3 ними відповідні установи, творчі спілки, асоціації та ін.

Сутність психологічної функції - застосування різних видів консультування і корекції міжособистісних стосунків, сприяння соціальній адаптації індивіда, допомога в соціальній реабілітації всім, хто цього потребує [12].

Чільне місце в діяльності соціального працівника займає соціально-побутова функція, що полягає у наданні необхідної допомоги й підтримки різним категоріям населення в поліпшенні їх житлових умов, облаштуванні, веденні домашнього господарства тощо.

Нарешті, комунікативна функція передбачає встановлення контактів з клієнтами, організацію обміну інформацією, формування єдиної стратегії взаємодії сприймання і розуміння іншої людини $[10 ; 11]$.

Для виконання цих функцій сучасний фахівець соціальної сфери повинен бути різноплановим: спеціалістом в галузі соціальної інженерії та технологій, який добре орієнтується у правових, моральних та психологічних особливостях життєдіяльності людей, володіє високою юридичною підготовленістю, медико-психологічною компетентністю, знанням іноземної мови професійного спрямування, що є вкрай необхідним для роботи з різними клієнтами, володіти високими моральними якостями. Оскільки функції і поле діяльності фахівців соціальної сфери дуже широкі і різноманітні, то підготовка фахівців такого профілю набуває специфічних ознак, пов'язаних з необхідністю забезпечення набуття ними знань у різних галузях: юридичній, психологічній, медичній, педагогічній, соціологічній, комунікативній та інших [12: 224-227].

Специфіка підготовки фахівців соціальної сфери полягає у тому, що по-перше, фахівець соціальної сфери, у межах своєї професійної діяльності, взаємодіє з великою кількістю джерел інформації, причому не певної конкретної галузі, а водночас багатьох: отримує інформацію юридичного, економічного, медичного, соціального, педагогічного, психологічного характеру. Фахівець соціальної сфери мусить не лише володіти фаховими знаннями з психології, соціології, психіатрії, знати законодавство, правові аспекти соціального захисту, теорії та методи соціальної роботи, наявні ресурси та методи їх використання, а й володіти іноземною мовою професійного спрямування, адже ця інформація може надходити з різних джерел та різними мовами; уміти спілкуватися та надавати інформацію (бажано декількома мовами), оцінювати потреби та представляти інтереси людини в умовах полікультурного та полілінгвального середовища.

По-друге, професійна підготовка вимагає від фахівців соціальної сфери професійних знань (організації системи соціального забезпечення, законодавства щодо соціальних проблем, засобів, методів, форм i прийомів роботи 3 різними категоріями клієнтів та сімей, особливостей роботи у громаді, 3 певними групами клієнтів соціального виключення), та специфічного підходу до вирішення кожної окремої проблеми, адже характер таких проблем, з якими вона стикається, не дає можливості запропонувати однозначні методи їх ефективного вирішення. Для вироблення специфічного підходу молодому фахівцю вкрай необхідно ознайомитись із досвідом фахівців щодо вирішення тих чи інших проблем, у тому числі міжнародним досвідом, що можливо за умови володіння іноземною мовою професійного спрямування. 
По-третє, оскільки темпи розвитку суспільства $\epsilon$ надзвичайно високими, то спостерігається перенасиченість ринку праці, що підвищує вимоги до рівня професіоналізму фахівців соціальної сфери. Багато проектів створюються у співробітництві з іншими країнами, де соціальна служба допомоги стоїть на більш високому рівні. Це дає унікальну можливість вчитися на уроках міжнародного досвіду. Такі можливості відкриваються студентам, які проходили навчання на білінгвальній основі (викладання дисциплін фахового спрямування здійснювалося іноземною мовою), що у подальшому дає їм можливість не лише долучитися до міжнародного досвіду, а стати частиною наукового співтовариства [13: 224-227].

Таким чином, навчання на білінгвальній основі, потреба у якому зумовлюється вищезазначеними факторами, надасть можливість майбутнім фахівцям соціальної сфери долучитися до світових надбань в галузі соціальної роботи, що, в свою чергу, розширить професійні можливості фахівця щодо його професійного розвитку та самовдосконалення.

Отже, з точки зору освітніх потреб та можливих способів їх реалізації, на сучасному етапі розвитку українського суспільства вважаємо білінгвальну освіту необхідним елементом підготовки сучасного фахівця соціальної сфери. Адже на хвилі соціального оновлення суспільства, бажання долучитися до європейського культурно-освітнього простору, а також можливості надавати соціальні послуги широкому колу клієнтів, користуватися сучасними світовими надбаннями у галузі соціальної роботи та приєднатися до світової наукової спільноти, білінгвальна підготовка є доречною.

Серед перспектив подалыших досліджень професійної підготовки майбутніх фахівців соціальної сфери на білінгвальній основі вбачаємо розробку навчально-методичного забезпечення для такого способу навчання.

\section{СПИСОК ВИКОРИСТАНИХ ДЖЕРЕЛ ТА ЛІТЕРАТУРИ}

1. Мигович I. І. Соціальна робота (вступ до спеціальності) / І. І. Мигович. - Ужгород : Ужгород. держ. ун-Т., 1997. $-190 \mathrm{c}$.

2. Актуальні проблеми соціальної сфери : [збірник наукових робіт викладачів і студентів] ; за заг. ред. Н. П. Павлик]. - Житомир : Вид-во Житомирського державного університету імені Івана Франка, 2015. Вип. 4. $-158 \mathrm{c}$.

3. Закон України "Про вищу освіту" : за станом на 5 вер. 2017 р. : офіц. вид. Верховна Рада України. - Київ : Парлам. вид-во, 2017. - 49 с.

4. Файчук О. Л. До питання професійної підготовки майбутніх соціальних працівників / О. Л. Файчук. - Витоки педагогічної майстерності. - Серія : Педагогічні науки. 2012. - Вип. 10. - С. 299-302. - Режим доступу : http://nbuv.gov.ua/UJRN/ vpm 2012_10_65 (дата звернення : 02.05.20015).

5. Поліщук В. А. Професійна підготовка фахівців соціальної сфери: зарубіжний досвід : [посібник]/ В. А. Полішук. - Тернопіль : Навчальна книга - Богдан, 2003. - С. 139-142.

6. Капська А. Й. Ступенева система професійної підготовки фахівців соціально-педагогічної сфери / А. Й. Капська // Науковий часопис. - Серія 11. - Київ : НПУ імені М. П. Драгоманова. 2004. - 1 (23). - С. $19-29$.

7. Матвійчук Т. В. Особливості професійної підготовки соціальних працівників: регіональний аспект // Збірник наукових праць Хмельницького інституту соціальних технологій Університету "Україна". - № 1 (9) / 2014. C. $82-86$.

8. Лукашевич М. П. Теорія і методи соціальної роботи : [навч. посіб] / М. П. Лукашевич, І. І. Мигович. - Київ, 2002. $-136 \mathrm{c}$.

9. Національний класифікатор України. Класифікатор професій - 2016. - Режим доступу : https://jobs.ua/ukr/ classifier/dopolnenie-B/let-154/page-8 (дата звернення : 28.07.2018).

10. Соціальна робота в Україні : [навч. посібник] / І. Д. Звєрєва, О. В. Безпалько, С. Я. Харченко та ін.; за заг. ред. І. Д. Звєрєвої, Г. М. Лактіонової. - Київ : Науковий світ, 2003. - 233 с.

11. Агранат Ю. В. Социальная работа: что это значит? Social Work : What Does It Mean? / Ю. В. Агранат. - Изд-во ДВГУПС, 2006. - $132 \mathrm{c}$.

12. Енциклопедія для фахівців соціальної сфери. - 2-ге видання. - За заг. ред. проф. І. Д. Звєрєвої. - Київ, Сімферополь : Універсум, 2013. - 536 с.

13. Романовська Л. І. Підготовка майбутніх соціальних педагогів до професійної діяльності та позитивні тенденції такого процесу в Україні / Л. І. Романовська // Збірник наукових праць Хмельницького інституту соціальних технологій Університету "Україна", № 2 (8), 2013. - С. 224-227.

\section{REFERENCES (TRANSLATED \& TRANSLITERATED)}

1. Myhovych I. I. Sotsial'na robota (vstup do spetsial'nosti) [Social Work (Introduction to Speciality)] / I. I. Myhovych. Uzhhorod : Uzhhorod. derzh. un-t. Publ., 1997. - 190 p.

2. Aktual'ni problemy sotsialnoi sfery : [Topical Issues of Social Work] : [zbirnyk naukovykh robit vykladachiv i studentiv, red. N. Pavlyk]. - Zhytomyr : Zhytomyr Ivan Franko State University. - Publ., 2015, Issue 4. - 158 p.

3. Zakon Ukrainy "Pro vyshchu osvitu" [The Low of Ukraine "On Higher Education"] : za stanom na 5 ver. 2017 r. : ofits. vyd. Verkhovna Rada Ukrainy. - Kyiv : Parlam. Publ., 2017. - 49 p.

4. Faichuk O. L. Do pytannia profesiinoi pidhotovky maibutnikh sotsial'nykh pratsivnykiv [On the Issue of the Professional Training of Future Social Workers] / O. L. Faichuk. - Vytoky pedahohichnoi maisternosti. Issue : Pedahohichni nauky. 2012, No. 10. - Pp. 299-302. - Rezhym dostupu : http://nbuv.gov.ua/UJRN/vpm 20121065. 
5. Polishchuk V. A. Profesiina pidhotovka fakhivtsiv sotsialnoi sfery: zarubizhnyi dosvid [Professional Training of Specialists in the Social Sphere : Foreign Experience] : [posibnyk]. - Ternopil : Navchalna knyha - Bohdan Publ., 2003. - Pp. 139-142.

6. Kapska A. Y. Stupeneva systema profesiinoi pidhotovky fakhivtsiv sotsial'no-pedahohichnoi sfery [Graduate System of Professional Training of Specialists in the Social-Pedagogical Sphere] // Naukovyi chasopys [Scientific Journal]. Issue 11. - Kyiv : NPU Publ., 2004. 1 (23). - Pp. 19-29.

7. Matviichuk T. V. Osoblyvosti profesiinoi pidhotovky sotsialnykh pratsivnykiv: rehional'nyi aspekt [Peculiarities of Professional Training of Social Workers: Regional Aspect]: [zbirnyk naukovykh prats' Khmelnytskoho instytutu sotsialnykh tekhnolohii Universytetu "Ukraina"]. - No. 1(9) / 2014. - Pp. 82-86.

8. Lukashevych M. P. Teoriia i metody sotsialnoi roboty [Theory and Methodology of Social Work] : [navch. posib]/ M. P. Lukashevych, I. I. Myhovych. - Kyiv, 2002. - 136 p.

9. Natsionalnyi klasyfikator Ukrainy [National Classifier of Ukraine]. - Klasyfikator profesii - 2016. - Rezhym dostupu : https://jobs.ua/ukr/ classifier/dopolnenie-B/let-154/page-8.

10. Zvierieva I. D. Sotsial'na robota v Ukraini [Social Work in Ukraine] : [navch. posibnyk] / I. D. Zvierieva, O. V. Bezpalko, S. Ya. Kharchenko ta in.; za zah. red. I. D. Zvierievoi, H. M. Laktionovoi. - Kyiv : Naukovyi svit Publ., 2003. -233 p.

11. Ahranat Yu. V. Sotsyal'naia rabota: chto eto znachyt? [Social work: what does it mean?] / Yu. V. Ahranat. - DVHUPS Publ., 2006. $-132 \mathrm{p}$.

12. Entsyklopediia dlia fakhivtsiv sotsial'noi sfery [Encyclopedia for Professionals in the Social Sphere]. - 2-he vydannia. Za zah. red. prof. I. D. Zvierievoi. Kyiv, Simferopol : Universum Publ., 2013. - 536 p.

13. Romanovska L. I. Pidhotovka maibutnikh sotsial'nykh pedahohiv do profesiinoi diial'nosti ta pozytyvni tendentsii takoho protsesu v Ukraini [Preparation of Future Social Pedagogues for Professional Activity and Positive Tendencies of Such a Process in Ukraine] : [zbirnyk naukovykh prats' Khmelnytskoho instytutu sotsialnykh tekhnolohii Universytetu "Ukraina"] / L. I. Romanovska. - No. 2 (8), 2013. - Pp. 224-227.

Ситняковская С. М. Специфика подготовки будущих специалистов социальной сферы в
отечественной высшей школе как фактор билингвальной профессиональной подготовки.

В данной статье представлена специифика подготовки будущчих специилистов социальной сферы $в$ отечественной высшей школе, которая выступает фактором профессиональной подготовки таких спечиалистов на билингвальной основе.

Доказано, что с точки зрения образовательных потребностей и возможных способов их реализаџии, на современном этапе развития украинского общества билингвальное образование является необходимьлм элементом подготовки современного специилиста социальной сферы.

Ключевые слова: билингвальная профессиональная подготовка, обучение на билингвальной основе, специалисты социальной сферы.

\section{Sytnyakivska S. M. The Specifics of Training Future Social Sphere Specialists in the National Higher Educational Institutions as a Factor of Bilingual Professional Training.}

This article presents the specifics of training future social sphere specialists in the national higher educational institutions, which is a factor of the professional training of such specialists on a bilingual basis. It is proved that due to the educational needs and possible ways of its realization at the modern stage of the development of Ukrainian society, bilingual education is an essential element in the teaching process of a modern social sphere specialist. As, on the wave of social renewal of society, the desire of our country to join the European cultural and educational space, as well as the opportunity to provide social services to a wide range of clients, use modern world achievements in the field of social work and join the world scientific community, bilingual education of future social sphere specialists is necessary.

Also, the article highlighted the factors that influence the specifics of future specialists professional training. Such factors are: interaction of a specialist with a large number of different sources of information, the need for exchange of experience of different specialists in solving certain problems, including international experience, which is possible if the professional foreign language is fluent, the overcrowding of the labor market, which raises the requirements to the professional level of specialists in social sphere.

Key words: bilingual professional training, bilingual-based education, social sphere specialists. 